Archive for

Organic Chemistry

Arkivoc 2019, part v, 50-59

\title{
Regio - and stereoselective synthesis of the iminosugars - 4-substituted 1-benzylpiperidine-3,5-diols
}

\author{
Ivan S. Veselov*, Alexandr M. Petrenko, Dmitriy M. Mazur, and Galina V. Grishina* \\ Department of Chemistry, Moscow State University, 119991, Moscow, Russia \\ Email: ivan@aroma-os.ru,grishina@org.chem.msu.ru
}

Received 08-03-2018

Accepted 11-28-2018

Published on line 02-13-2019

\section{Abstract}

We report a new approach to preparing iminosugars - 4-substituted 1-benzylpiperidin-3,5-diols by reaction of 1-benzyl-4,5-epoxypiperidine-3-ols in the presence of lithium perchlorate. This regio- and stereoselective synthesis proceeds via successive nucleophilic cleavage of 1-benzyl-4,5-epoxypiperidin-3-ols by benzylamine, thiophenol and diallylamine. Initial 1-benzyl-4,5-epoxypiperidin-3-ols were obtained by oxidation of trifluoroacetates of 1-benzyl-1,2,3,6-tetrahydropyridin-3-ols.<smiles>[R]C1C=CC(O)CN1Cc1ccccc1</smiles>

Keywords: Epoxypiperidines, iminosugars, stereoselective synthesis, polyhydroxylated piperidines 


\section{Introduction}

Functionalized piperidines are versatile synthons for the directed design of synthetic analogues of diverse piperidine alkaloids and are common structural targets in pharmacological research. ${ }^{1-3} \mathrm{~A}$ new interesting research area has recently emerged regarding polyhydroxylated piperidines as enzymatic inhibitors particularly for glycosidases, sialidases or neuraminidases. ${ }^{1,2}$ Iminosugars are potentially useful for the therapy of the metabolic disorders such as diabetes, viral and bacterial infections, tumors, lysosomal storage diseases. ${ }^{3,4}$ For instance, the alkaloid nojirimycin $\mathbf{1}$ is a strong inhibitor of $\alpha$-and $\beta$-glucosidases involved in the metabolism of carbohydrates. Some derivatives of polyhydroxylated piperidines 1-6, for example 1deoxynojirimycin $\mathbf{2}$ are used for the treatment of Alzheimer's disease ${ }^{5}$ and Farby disease. ${ }^{6}$
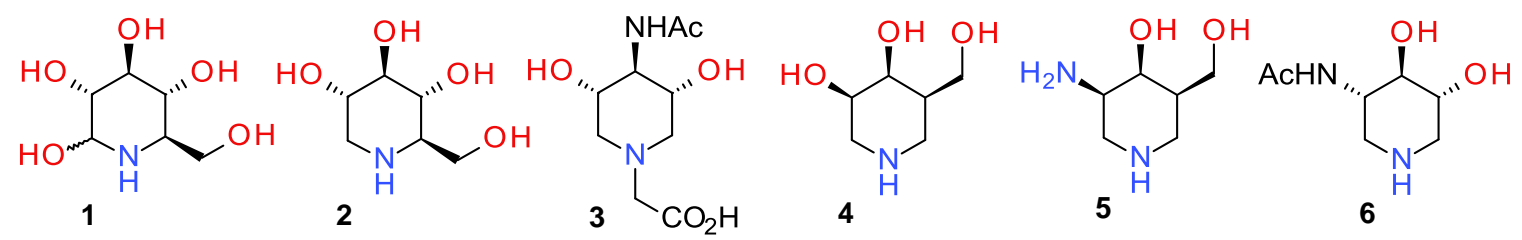

Figure 1. The hydroxylated piperidine alkaloids 1-6.

It has been found ${ }^{7-10}$ that introduction of an amino group into the structure of iminosugars (compounds $3,5,6)$ leads to a change of their activity towards enzyme targets. For example, 4-acetamido-3,5dihydroxypiperidine $\mathbf{3}$ inhibits sialidase - a virus neuroaminidases incorporated in the membranes of certain viruses. Galactoisofagomine $\mathbf{4}$ is an inhibitor of $\mathbf{B}$-galactosidase, while its counterpart 3-azaanalog 5 with the same configuration of stereocentres selectively inhibits 6 -glucosidase. ${ }^{7,8}$ Stereochemical analogue of galactoisofagomine 3-acetaminopiperidine 6 selectively inhibits $B-N$-acetylglucosaminidase and is not active towards other types of glycosidases. ${ }^{9,10}$ High therapeutic potential of iminosugars, in particular analogues 1-6, stimulated intensive structural and stereochemical studies of new iminosugars. The same is true for the development of new practical and selective methods for the synthesis of iminosugars ${ }^{11-13}$ and their analogues using enzymatic and asymmetric methods. ${ }^{14-16}$ There is a limited number of approaches suitable for the preparation of 3,4,5-trisubstituted and 2,3,4,5-tetrasubstituted piperidines. ${ }^{15,16}$ For this reason, the development of convenient and effective ways of synthesis of polysubstituted piperidines would significantly increase chance of finding new selective inhibitors.

\section{Result and Discussion}

We report here a novel approach to regio- and stereoselective synthesis of 4-substituted 1-benzylpiperidin3,5-diols 10a-e via nucleophilic cleavage of convenient key 1-benzyl-4,5-epoxypiperidin-3-ols 9a-c by benzylamine, diallylamine and thiophenol in $\mathrm{CH}_{3} \mathrm{CN}$ at room temperature with yields $55-78 \%$ in the presence of hard Lewis acid ( 2 equivalents of lithium perchlorate).

We have previously developed a regio- and stereospecific synthesis of racemic and enantiopure trans-4amino-1-benzylpiperidin-3-ols ${ }^{17,18}$ via nucleophilic ring opening of epoxide 7a under mild conditions with high yields in the presence of Lewis acid (lithium perchlorate, 1 equivalent). There is a general consensus that this outcome of the nucleophilic ring opening is promoted by the bidentate coordination of epoxide 7a organized 
to produce only 4-substituted regioisomer. ${ }^{19-23}$ Such coordination activates the epoxide ring for the nucleophilic attack and shifts the conformational equilibrium (originally in favor the anti-conformer $\mathbf{A}$ by $\sim 1.6$ $\mathrm{kcal} / \mathrm{mol}^{17}$ ) entirely towards the lithium complex of syn-conformer B, producing only 4-substituted regioisomer upon the epoxide cleavage.
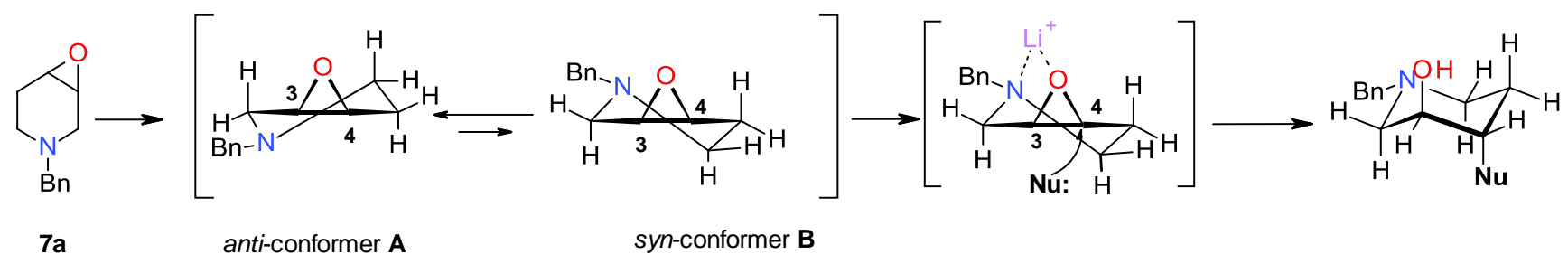

syn-conformer B

Scheme 1. Regio- and stereospecific ring opening of 1-benzyl-3,4-epoxypiperidine 7a.

The regio- and stereospecific synthesis of the trans-3-amino-1-benzylpiperidine-4-ols was also performed using the complex of a hard Lewis acid diisobutylaluminum hydride (DIBAL-H) with Lewis bases - primary and secondary amines. ${ }^{24-25}$

The present work proceeds the stereochemical investigations of nucleophilic ring opening of epoxypiperidines 7a-c. Targeted 4-substituted 1-benzylpiperidine-3,5-diols 10a-e which are stereochemical analogues of iminosugars 1-6, were prepared according to Scheme $\mathbf{2}$. The initial 1-benzyl-4,5-epoxypiperidine3-ols 9a-c were produced by oxidation of trifluoroacetates of 1-benzyl-1,2,3,6-tetrahydropyridine-3-ols 8a-c with trifluoroperacetic acid (5 equivalents) at $0^{\circ} \mathrm{C}$ in anhydrous $\mathrm{CH}_{2} \mathrm{Cl}_{2}{ }^{17,26}$

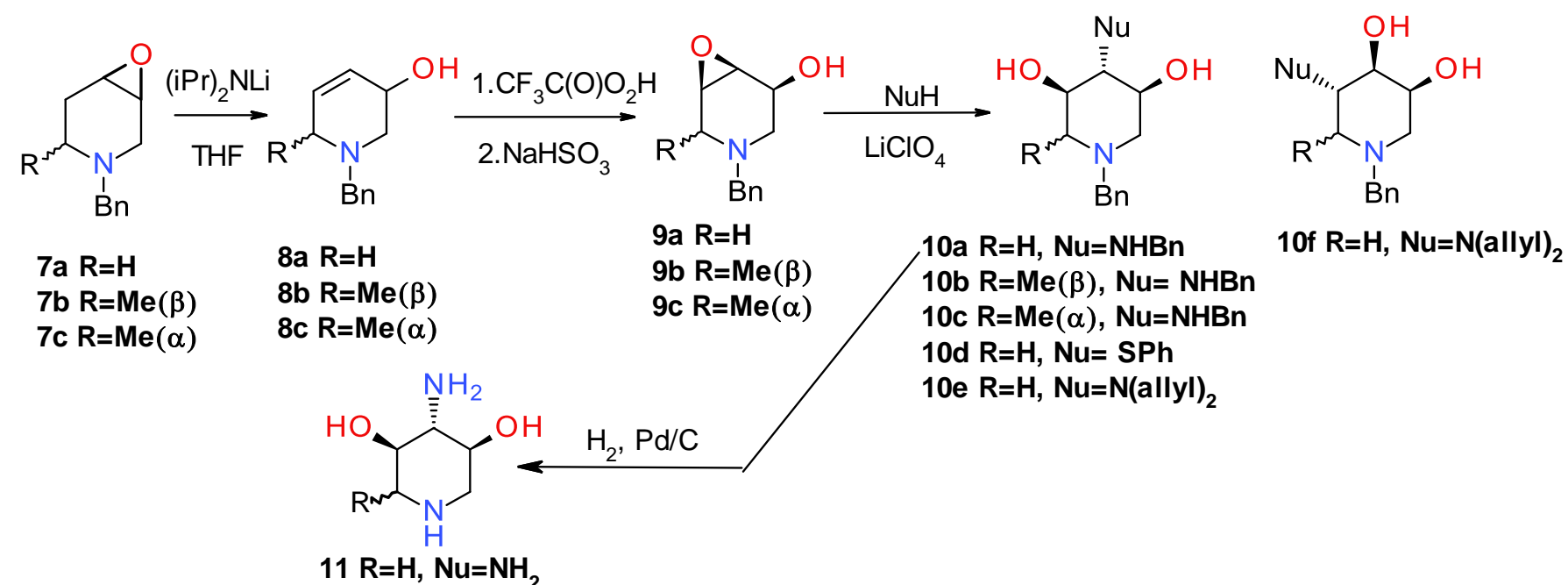

Scheme 2. The sequence of synthesis steps of 4-substituted 1-benzylpiperidine-3,5-diols 10a-e, 11.

The key allyl alcohols 8a-c were produced by rearrangement of 1-benzyl-3,4-epoxy piperidines 7a-c under the influence of lithium diisopropylamide in THF at $-70^{\circ} \mathrm{C}$ under argon atmosphere. ${ }^{18}$ Epoxidation of the allyl alcohol 8 a generates a single compound with a mass molecular ion $(\mathrm{m} / \mathrm{z} 205)$ corresponding to the epoxy alcohol 9a, which was isolated by column chromatography on silica gel with $63 \%$ yield. The epoxy alcohols $9 \mathbf{b}, \mathbf{c}$ were produced with the 58-65\% yields under similar conditions. Formation of the epoxy alcohols 9a-c was confirmed by the presence of a signal at 50-60 ppm and at $65 \mathrm{ppm}$ in ${ }^{13} \mathrm{C}$ NMR spectra, which are typical for 
C-4/C-5 atoms of 1-benzyl-4,5-epoxy piperidines ${ }^{26}$ and the C-3 hydroxyl group, respectively. The pseudo equatorial direction of the 3-hydroxy group was determined based on the large vicinal coupling constant ${ }^{3} J_{2 a, 3 a}$ (7-8 Hz) of the axial protons connected to the $\mathrm{C}-2$ and $\mathrm{C}-3$ stereocenters of the piperidine core. Basing on NMR ${ }^{1} \mathrm{H}$ and ${ }^{13} \mathrm{C}$ spectral data, it was found that the epoxidation proceeds as a syn process and leads to the formation of epoxides 9a-c with cis orientation of epoxy and the 3-hydroxy groups.

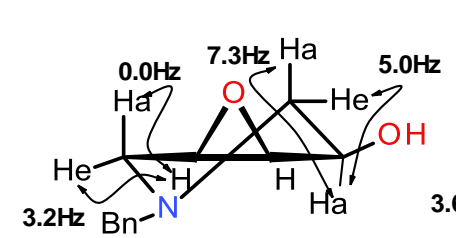

$9 a$

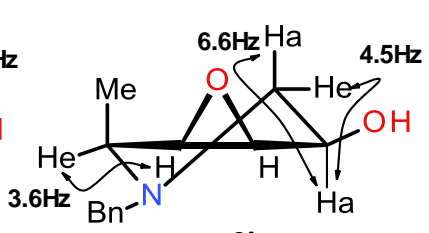

$9 b$

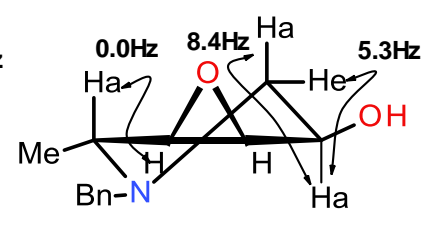

9c

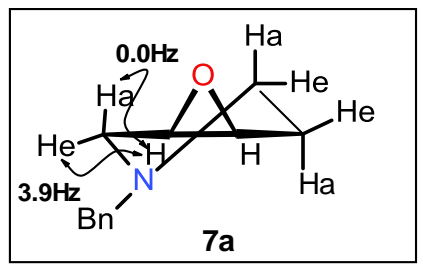

$7 a$

Figure 2. Preferred anti-conformation half chair of the epoxy alcohols 9a-c with cis-orientation of 4,5-epoxy and pseudo equatorial 3-hydroxyl groups.

We assume that high syn stereoselectivity of the epoxidation of allyl alcohols $\mathbf{8 a - c}$ is connected with the assistance of 3-hydroxyl group due to formation of the intermediates I or II, stabilized by hydrogen bonds, including the nitrogen atom of the piperidine cycle. Apparently, the peculiarities of a Lewis acid coordinating with epoxide must play a significant role in the relative stability and structure of the reaction intermediates.
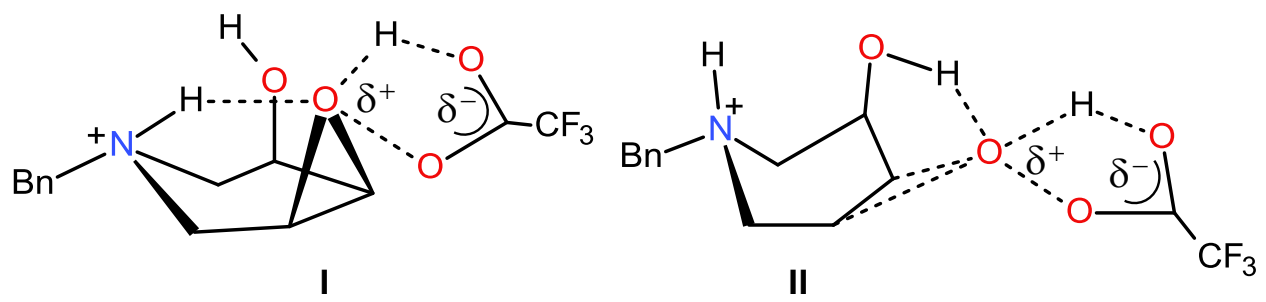

Figure 3. Plausible structures of intermediates I and II.

Consequently, syn-epoxidation of allyl alcohols 8a-c leads to the formation of the epoxy alcohols 9a-c of preferably in anti-conformation half chair with pseudo equatorial 3-hydroxyl group. (Figure 2). Previously synstereoselectivity has been observed upon epoxidation of $N$-ethoxycarbonyl-3-hydroxy-1,2,3,6tetrahydropyridine with a free 3-hydroxy group. However, a decrease in syn-stereoselectivity with dominated anti-isomer has been reported for oxidation of $N$-carbamoyl-1,2,3,6-tetrahydropyridine with protected 3hydroxy group (3-benzyloxy-, 3-acetoxy-, 3-tert-butyldiphenylsilyloxy-groups). ${ }^{27-29}$

Next, we carried out stereoselective synthesis of targeted 4-substituted 1-benzylpiperidine-3,5-diols 10a-e via nucleophilic cleavage of the epoxy alcohols $9 a-c$ with benzylamine, thiophenol and diallylamine. Reactions were performed in anhydrous $\mathrm{CH}_{3} \mathrm{CN}$ at room temperature in the presence of lithium perchlorate (two equivalents) with good yields. According to ${ }^{1} \mathrm{H}$ NMR and chromatographic monitoring, the ring opening of epoxy alcohols 9a-c with benzylamine and thiophenol afforded single regio- and stereoisomer 4-substituted $(3 R, 4 r, 5 S)$-1-benzylpiperidines 10a,b,e and racemic 1-benzyl-2-methyl-4-benzylaminopiperidine-3,5-diols 10c,d which were isolated with $55-71 \%$ yields. Under the same experimental conditions, the opening of epoxy alcohol 9a with diallylamine afforded a mixture of $10 \mathrm{e}$ and 10 in a ratio of $4: 1$, according to ${ }^{1} \mathrm{H}$ NMR spectra of the reaction mixture. These compounds were easily separated by column chromatography and were isolated 
in 64 and $12 \%$ yield, respectively. Also the $(3 R, 4 r, 5 S)$-4-aminopiperidine-3,5-diol 11 was obtained by removing of both benzyl groups from the compound 10a through hydrogenolysis above $\mathrm{Pd} / \mathrm{C} 10 \%$ in $\mathrm{CH}_{3} \mathrm{OH}$ with $82 \%$ yield.

According to ${ }^{1} \mathrm{H}$ NMR spectra the major isomer $10 \mathrm{e}$ is 1-benzyl-4-diallylaminopiperidine-3,5-diol and the minor one 10 is 1-benzyl-5-diallylaminopiperidine-3,4-diol. Furthermore, masses of protonated molecules $\left([\mathrm{M}+\mathrm{H}]^{+}\right)$10a, 10e were measured within 2 ppm mass accuracy: $\mathrm{C}_{19} \mathrm{H}_{25} \mathrm{~N}_{2} \mathrm{O}_{2} \mathrm{~m} / z \quad 313.19159$ (calculated 313.1911), $\mathrm{C}_{18} \mathrm{H}_{27} \mathrm{O}_{2} \mathrm{~N}_{2} \mathrm{~m} / \mathrm{z} 303.20719$ (calculated 303.2067) respectively. The most intensive fragment ions in the MS/MS spectra of the studied compounds corresponded to loss of $\mathrm{H}_{2} \mathrm{O}, \mathrm{NH}_{3}$ molecules $\left(\mathrm{NH}_{2} \mathrm{Bn}\right.$ or $\mathrm{NH}(\text { allyl })_{2}$ correspondingly), both consequently or 2 molecules of $\mathrm{H}_{2} \mathrm{O}$. All together these facts reveal the proposed structures of 4-substitued 1-benzylpiperidin-3,5-diols. This is another case where the regio- and stereoselectivity of the nucleophilic attack on the epoxide ring at C-4 yields predominantly the 4-substituted 1benzylpiperidine-3,5-diol 10e, though with some decrease in the regioselectivity. Spatial structures of amino alcohols $10 a, d, e$ were established according to the general view of their ${ }^{13} \mathrm{C} \mathrm{NMR}$ spectra. For aminodiol $10 \mathrm{a}$ there are 3 carbon signals of the piperidine ring at 59.3 ppm (C2, C6), 67.7 ppm. (C4) and 69.8 ppm. (C3, C5), which are similar for all of the 3,4,5-trisubstituted piperidine derivatives 10a,d,e. Equatorial arrangement of the 3,5-dihydroxy groups and a substituent at C-4 in 10a-e is established in accordance with the values of vicinal coupling constants ${ }^{3} J_{3 a, 4 a}$ and ${ }^{3} J_{4 a, 5 a}(8-10 \mathrm{~Hz})$. In the minor 1-benzyl-5-diallylaminopiperidine-3,4-diol $10 f$ the trans-diequatorial orientation of the 4-hydroxy and 5-diallylamino groups was determined according the values of vicinal coupling constants ${ }^{3} J_{5 a, 6 a}$ and ${ }^{3} J_{5 a, 4 a}(10.9$ and $10.6 \mathrm{~Hz})$ of axial protons, respectively. The value of vicinal coupling constant ${ }^{3} J_{3,4}(3.3 \mathrm{~Hz})$ of the proton at $\mathrm{C} 3$ corresponds to the axial orientation of hydroxyl group at C-3.

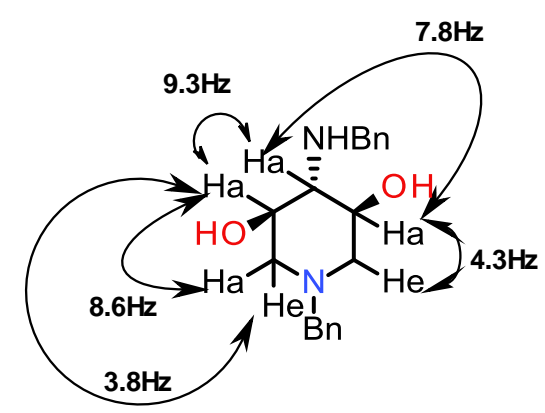

$10 a$

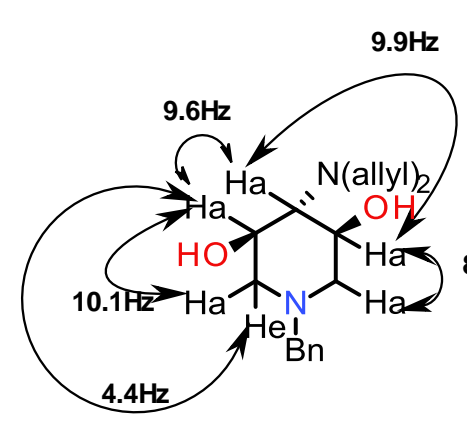

$10 \mathrm{e}$

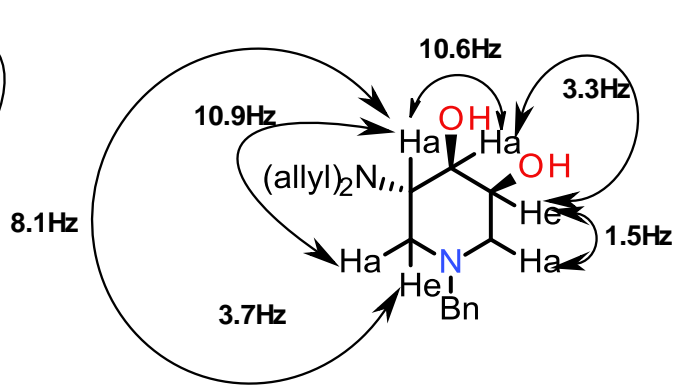

$10 f$

Figure 4. The values of vicinal coupling constants $(\mathrm{Hz})$ of the protons in 1-benzylpiperidinediols 10 a,e,f.

The structure and stereochemistry of the 4-substituted 1-benzylpiperidine-3,5-diols 10a-e, 11 were confirmed by the spectral and elemental analysis of their free bases or dihydrochlorides.

It should be emphasized that according to the rule of Fuerst-Plattner ${ }^{30}$, the nucleophilic opening of the epoxy alcohols 9a-c must pass "trans-diaxially", preferably by the C-5 position of the anti-conformer $\mathbf{C}$, with the formation of 5-substituted 1-benzylpiperidine-3,4-diols of the "10f" type. 


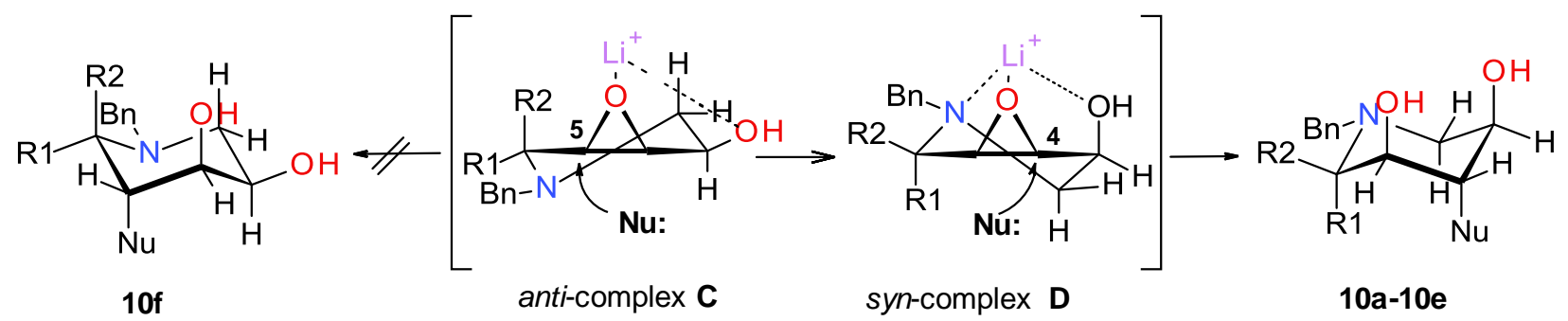

Scheme 3. Plausible mechanism of the nucleophilic opening of the epoxy alcohols $\mathbf{9}$ a-c.

However, our stereochemical study indicated the preservation of the dominant regio- and stereoselective ring opening of epoxyalcohols $9 \mathrm{a}-\mathrm{c}$ at the $\mathrm{C}-4$ position of the piperidine core with the formation of

4-substituted 1-benzylpiperidine-3,5-diols 10a-e. The observed highly regioselective opening at the C4 position of the piperidine core can be explained by the participation of a more preferred syn-complex $\mathbf{D}$, which is activated by a bidentate coordination of the lithium cation to the nitrogen atom of the piperidine core and the oxygen atoms of the 4,5-epoxy and 3-hydroxy groups.

\section{Conclusions}

We developed a new approach to a Lewis acid-catalyzed nucleophilic ring opening of 1-benzyl-4,5epoxypiperidine-3-ols 9a-c which leads to iminosugars - 4-substituted 1-benzylpiperidine-3,5-diols 10a-e, 11. The regio- and high stereoselective synthesis of 4-substituted 1-benzylpiperidine-3,5-diols 10a-e,11 opens a possibility for receiving the key intermediates for new iminosugar analogs and other bioactive compounds. We also developed the synthesis and performed conformational analysis of 1-benzyl-4,5-epoxypiperidine-3-ols 9ac, which are convenient polyfunctional blocks for the preparation of new biologically active polyhydroxylated and aminohydroxylated piperidine derivatives.

\section{Experimental Section}

General. The NMR spectra were recorded on Varian VXR-400 and Brucker DRX-500 spectrometers using $\mathrm{CDCl}_{3}$, $\mathrm{CD}_{3} \mathrm{OD}$ and DMSO- $d_{6}$ as solvents. Chemical shifts are given in $\delta(\mathrm{ppm})$ relative to TMS as internal standard. Elemental analysis was performed with a Perkin-Elmer 2400 CHNS elemental analyzer. GC-MS analysis was performed on spectrometer HP5989x-G and Finnigan SSQ7000, ionizing electrons energy 70 eV, capillary column DB5 $30 \mathrm{~m}$. The structures of 10a, 10e and 11 were confirmed with Orbitrap Elite mass-spectrometer (Thermo Fisher Scientific, USA) with an electrospray ionization (ESI) source. Formic acid (Sigma Aldrich, St. Louis, Missouri, USA) was added to the methanol solutions of all samples for the analysis in positive mode. The system was controlled by the Xcalibur software, which was also used for data collection and data processing. The methanol solution of each compound was introduced through syringe pump directly into the ion source at $5 \mu \mathrm{l} / \mathrm{min}$. Sheath gas flow rate was from 10 to 25 arbitrary units, auxiliary and sweep gas flow rate was set to zero. Capillary temperature was set to $275^{\circ} \mathrm{C}$ and spray voltage to $3.5 \mathrm{kV}$. Accurate mass measurements were carried out in Orbitrap analyzer with 480000 resolving power. Elemental composition of each fragment ion was calculated within 5 ppm mass accuracy. MS/MS experiments were carried out using both collision induced dissociation (CID) fragmentation triggering techniques at 20 arbitrary units. Nitrogen was used as collision gas. 
The scanned masses in CID were settled from 85 to $500 \mathrm{Da}$, mass window was $1 \mathrm{Da}$. The spectra were recorded during $30 \mathrm{~s}$. Silica gel 60 (230-400 mesh) was used for flash column chromatography. Silufol was used for TLC.

1-Benzyl-3,4-epoxypiperidines 7a-c and 1-benzyl-1,3,5,6-tetrahydropyridine-3-ols 8a-c were prepared according to the procedures described previously. ${ }^{17,18}$

General method for preparation of 1-benzyl-4,5-epoxypiperidine-3-ols 9a-c. To a mixture of $46.7 \%$ water solution of hydrogen peroxide $(0.34 \mathrm{~g}, 4.7 \mathrm{mmol})$ and anhydrous $\mathrm{CH}_{2} \mathrm{Cl}_{2}(5 \mathrm{ml})$ was added at $0{ }^{\circ} \mathrm{C}$ and vigorous stirring a solution of $\left(\mathrm{CF}_{3} \mathrm{CO}\right)_{2} \mathrm{O}(3.08 \mathrm{~g}, 14.5 \mathrm{mmol})$ in anhydrous $\mathrm{CH}_{2} \mathrm{Cl}_{2}(2 \mathrm{ml})$. The stirring at the same temperature was continued $1.5 \mathrm{~h}$. To thus obtained solution of $\mathrm{CF}_{3} \mathrm{C}(\mathrm{O}) \mathrm{O}_{2} \mathrm{H}(0.19 \mathrm{~g}, 1.0 \mathrm{mmol})$ prepared from 1-benzyl-1,2,3,6-tetrahydropyridine-3-ol (8a) (0.19 g, $1.0 \mathrm{mmol})$ and $\mathrm{CF}_{3} \mathrm{CO}_{2} \mathrm{H}$ in anhydrous $\mathrm{CH}_{2} \mathrm{CL}_{2}(3 \mathrm{ml})$ at 0 ${ }^{\circ} \mathrm{C}$. The epoxidation was monitored by TLC till complete consumption of initial 1-benzyl-1,2,3,6tetrahydropyridine-3-ol (8a). In $5 \mathrm{~h}$ the excess oxidant was decomposed by addition of aqueous $\mathrm{NaHSO}_{3}$ while vigorous stirring at $0-5{ }^{\circ} \mathrm{C}$. The organic layer was extracted with $\mathrm{CH}_{2} \mathrm{Cl}_{2}(4 \times 15 \mathrm{M})$. The combined organic extracts were dried with $\mathrm{Na}_{2} \mathrm{SO}_{4}$, the solvent was removed on a rotary evaporator. The crude product $(0.31 \mathrm{~g})$ was applied to a column packed with silica gel with hexane, gradient elution with system hexane-EtOAc, the content of EtOAc from 20 to $100 \%$. The organic extracts were combined, the solvent was removed in a vacuum.

(3SR,4SR,5RS)-1-Benzyl-4,5-epoxypiperidine-3-ol (9a). (0.23 g, 63\%), colorless oily substance, $R_{\mathrm{f}} 0.5$ (hexane / $\left.\mathrm{CH}_{3}\right)_{2} \mathrm{CO}$ 4:1). MS, m/z (Irel.\%): 205 (3) [M 188 (1), 176 (1), 160 (3), 158 (3), 144 (1), 133 (28), 128 (1), 121 (1), 120 (14), 118 (2), 114 (2), 104 (3), 91 (100). ${ }^{1} \mathrm{H}$ NMR (400 MHz, CDCl $) \delta 2.15$ (bs, 1H, OH), 2.22 (dd, J $11.4,7.0$ $\mathrm{Hz}, 1 \mathrm{H}, \mathrm{H} 2_{\mathrm{a}}$ ), 2.51 (ddd, J 11.4, 5.0, 1.2 Hz, 1H, H2 ), 2.75 (bd, J 13.5 Hz, 1H, H6a), 2.81 (bdd, J 13.5, 1.2 Hz, 1H, $\mathrm{H} 6 \mathrm{e}), 3.40(\mathrm{~m}, 2 \mathrm{H}, \mathrm{H} 4, \mathrm{H} 5), 3.49\left(\mathrm{~s}, 2 \mathrm{H}, \mathrm{Ph}-\mathrm{CH}_{2}\right), 4.05\left(\mathrm{~m}, \mathrm{~J} 7.0,5.0 \mathrm{~Hz}, 1 \mathrm{H}, \mathrm{H} 3_{\mathrm{a}}\right), 7.21-7.32(\mathrm{~m}, 5 \mathrm{H}, \mathrm{Ph}) .{ }^{13} \mathrm{C} \mathrm{NMR}$ $\left(100 \mathrm{MHz} \mathrm{CDCl}_{3}\right) \delta 50.8,53.6(2 \mathrm{C}), 61.5,65.4,70.8,127.6,128.4(2 \mathrm{C}), 129.2(2 \mathrm{C}), 136.4$.

(3SR,4SR,5RS,6SR)-1-Benzyl-6-methyl-4,5-epoxypiperidine-3-ol (9b) (0.16 g 63\%) was performed from cis-1benzyl-6-methyl-1,2,3,6-tetrahydropyridine-3-ol (8b) (0.22 g, $1.1 \mathrm{mmol})$. Reaction time $5 \mathrm{~h}$, colorless oil, $R_{\mathrm{f}} 0.6$ (hexane/(Me) $\left.{ }_{2} \mathrm{CO} 4: 1\right) .{ }^{1} \mathrm{H} \mathrm{NMR}\left(400 \mathrm{MHz}, \mathrm{CDCl}_{3}\right) \delta 1.25\left(\mathrm{~d}, J 6.6 \mathrm{~Hz}, 3 \mathrm{H}, \mathrm{CH}_{3}\right), 2.31(\mathrm{dd}, J 12.3,4.6 \mathrm{~Hz}, 1 \mathrm{H}, \mathrm{H} 2 \mathrm{e})$, 2.49 (dd, J 12.3, $6.6 \mathrm{~Hz}, 1 \mathrm{H}, \mathrm{H} 2_{\mathrm{a}}$ ), 2.61 (bs, $\left.1 \mathrm{H}, \mathrm{OH}\right), 2.97$ (dq, J 3.5, 6.6 Hz, 1H, H6 $), 3.31(\mathrm{dd}, J 3.8,3.5 \mathrm{~Hz}, 1 \mathrm{H}$, H5), 3.44 (dd, J 3.8, 3.5 Hz, 1H, H4), 3.44 (AB-system, J $13.6 \mathrm{~Hz}, 1 \mathrm{H}, \mathrm{Ph}-\mathrm{CH}_{2}$ ), 3.72 (AB-system, J 13.6 Hz, $1 \mathrm{H}, \mathrm{Ph}$ $\mathrm{CH}_{2}$ ), 3.95 (ddd, J 6.6, 4.6, 3.5 Hz, $1 \mathrm{H}, \mathrm{H} 3 \mathrm{a}$ ), 7.19-7.30 (m, 5H, Ph). ${ }^{13} \mathrm{C} \mathrm{NMR}\left(100 \mathrm{MHz}, \mathrm{CDCl}_{3}\right) \delta 12.6,51.1,51.8$, $53.5,57.0,58.9,64.9,127.1,128.3(2 \mathrm{C}), 128.7(2 \mathrm{C}), 138.5$.

(3SR,4SR,5RS,6RS)-1-Benzyl-6-methyl-4,5-epoxypiperidine-3-ol (9c) (0.23 g, 58\%), was performed from trans1-benzyl-2-methyl-1,2,3,6-tetrahydropyridine-3-ol (8c) $(0.40 \mathrm{~g}, 2.0 \mathrm{mmol})$. Reaction time $5 \mathrm{~h}$, colorless oil, $R_{\mathrm{f}}$ 0.6 (hexane/( $\left.\left.\mathrm{CH}_{3}\right)_{2} \mathrm{CO} 4: 1\right) .{ }^{1} \mathrm{H} \mathrm{NMR}\left(400 \mathrm{MHz}, \mathrm{CDCl}_{3}\right) \delta 1.27\left(\mathrm{~d}, J 6.8 \mathrm{~Hz}, 3 \mathrm{H}, \mathrm{CH}_{3}\right), 2.06(\mathrm{bs}, 1 \mathrm{H}, \mathrm{OH}), 2.09$ (dd, J 11.4, 8.4 Hz, 1H, H2 ) , $2.61\left(\mathrm{dd}, J 11.4,5.3 \mathrm{~Hz}, 1 \mathrm{H}, \mathrm{H} 2_{\mathrm{e}}\right.$ ), 2.88 (q, J $6.8 \mathrm{~Hz}, 1 \mathrm{H}, \mathrm{H} 6_{\mathrm{a}}$ ), $3.16(\mathrm{~d}, J 4.3 \mathrm{~Hz}, 1 \mathrm{H}, \mathrm{H} 5)$, 3.24 (AB-system, J $13.7 \mathrm{~Hz}, 1 \mathrm{H}, \mathrm{Ph}-\mathrm{CH}_{2}$ ), 3.38 (dd, J 4.3, 2.8 Hz, 1H, H4), 3.84 (AB-system, J 13.7 Hz, 1H, Ph$\mathrm{CH}_{2}$ ), 3.95 (ddd, J 8.4, 5.3, 2.3 Hz, $1 \mathrm{H}, \mathrm{H}_{\mathrm{a}}$ ), 7.19-7.30 (m, 5H, Ph). ${ }^{13} \mathrm{C} \mathrm{NMR}\left(100 \mathrm{MHz}, \mathrm{CDCl}_{3}\right) \delta$ 16.7, 50.0, 52.9, $53.4,58.2,59.3,66.5,127.1,128.3(2 \mathrm{C}), 128.7(2 \mathrm{C}), 138.3$.

General method for preparation of 4-substituted 1-benzylpiperidine-3,5-diols 10a-e. Anhydrous $\mathrm{LiClO}_{4}(0.11$ g, $1 \mathrm{mmol})$, was added to 1-benzyl-4,5-epoxypiperidine-3-ol (9a) $(0.10 \mathrm{~g}, 0.5 \mathrm{mmol})$ in anhydrous $\mathrm{CH}_{3} \mathrm{CN}(5 \mathrm{ml})$. The mixture was stirred until it became homogeneous, $\mathrm{BnNH}_{2}(0.05 \mathrm{~g}, 0,5 \mathrm{mmol})$ was added, and the mixture was stirred for $72 \mathrm{~h}$ at room temperature. The progress of the reaction was monitored by TLC following displacement of the initial epoxy derivative. The mixture was treated with brine $(1,5 \mathrm{ml})$, the solvent was distilled off under reduced pressure, and the resulting dispersion was extracted with $\mathrm{CH}_{2} \mathrm{Cl}_{2}(5 \times 1 \mathrm{M})$. The combined organic extracts were dried with $\mathrm{Na}_{2} \mathrm{SO}_{4}$, the solvent was removed on a rotary evaporator. 
$(3 R, 4 r, 5 S)$-1-Benzyl-4-benzylaminopiperidine-3,5-diol (10a) (0.08 g, 58\%). The crude product was white crystals, mp $186-187^{\circ} \mathrm{C}$ (from EtOAc). HRMS for $\left(\mathrm{C}_{19} \mathrm{H}_{25} \mathrm{~N}_{2} \mathrm{O}_{2}[\mathrm{M}+\mathrm{H}]^{+}\right)$Calcd: 313.1911. Found: 313.19159. Anal.

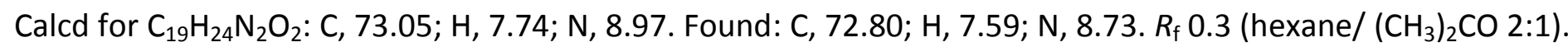
${ }^{1} \mathrm{H} N M R\left(400 \mathrm{MHz}, \mathrm{CD}_{3} \mathrm{OD}\right.$, DMSO $\left.d_{6}\right) \delta 1.78\left(\mathrm{t}, J 10.2 \mathrm{~Hz}, 2 \mathrm{H}, \mathrm{H} 2_{\mathrm{a}}, \mathrm{H} 6_{\mathrm{a}}\right), 2.15(\mathrm{t}, J 9.1 \mathrm{~Hz}, 1 \mathrm{H}, \mathrm{H} 4 \mathrm{a}), 2.78(\mathrm{dd}, J$

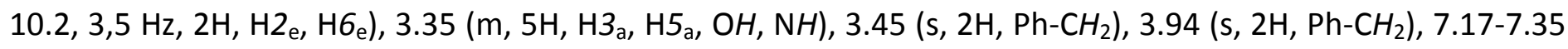
$(\mathrm{m}, 10 \mathrm{H}, 2 \times \mathrm{Ph}) .{ }^{13} \mathrm{C} \mathrm{NMR}\left(100 \mathrm{MHz}, \mathrm{CD}_{3} \mathrm{OD}\right.$, DMSO $\left.d_{6}\right) \delta 52.7,59.3(2 \mathrm{C}), 61.4,67.7,69.8(2 \mathrm{C}), 126.4,126.9$, $127.9(2 \mathrm{C}), 128.1(2 \mathrm{C}), 128.1(2 \mathrm{C}), 128.8(2 \mathrm{C}), 138.2,141.7$.

(2SR,3SR,4RS,5SR)-1-Benzyl-2-methyl-4-benzylaminopiperidine-3,5-diol (10b) (0.09 g,65\%) was performed from 1-benzyl-6-methyl-4,5-epoxypiperidin-3-ol (9b) $(0.09 \mathrm{~g}, 0.41 \mathrm{mmol})$ and $\mathrm{BnNH}_{2}(0.05 \mathrm{~g}, 0.41 \mathrm{mmol})$. The crude product was applied to a column packed with silica gel with hexane, gradient elution with system hexane/EtOAc, the content of EtOAc from 30 to 100\%. Reaction time $72 \mathrm{~h}$, pale yellow crystals, mp 133-134 $9 \mathrm{C}$ (from EtOAc). Anal. Calcd for $\mathrm{C}_{20} \mathrm{H}_{26} \mathrm{~N}_{2} \mathrm{O}_{2}$ : C, 73.59; $\mathrm{H}, 8.03 ; \mathrm{N}, 8.58$. Found: $\mathrm{C}, 73.40 ; \mathrm{H}, 7.79 ; \mathrm{N}, 8.32 . R_{\mathrm{f}} 0.5$ (hexane /( $\left.\left.\mathrm{CH}_{3}\right)_{2} \mathrm{CO} 2: 1\right) .{ }^{1} \mathrm{H} \mathrm{NMR}\left(400 \mathrm{MHz}, \mathrm{CDCl}_{3}\right) \delta 1.06\left(\mathrm{~d}, J 6.8 \mathrm{~Hz}, 3 \mathrm{H}, \mathrm{CH}_{3}\right), 2.49(\mathrm{dd}, J 11.4,8.6 \mathrm{~Hz}, 1 \mathrm{H}$, $\mathrm{H} 6_{\mathrm{a}}$ ), 2.56 (bs, 3H, OH, NH), 2.72-2.67 (m, 2H, H4a $\mathrm{H}_{\mathrm{e}}$ ), 3.14 (bd, J 4.3, 1H, H2 ), 3.64 (AB-system, J 13.4 Hz, 2H, Ph- $\left.\mathrm{CH}_{2}\right), 3.63-3.72\left(\mathrm{~m}, 2 \mathrm{H}, \mathrm{H}_{\mathrm{a}}, \mathrm{H} 5 \mathrm{a}\right), 3.97$ (AB-system, J $\left.12.9 \mathrm{~Hz}, 2 \mathrm{H}, \mathrm{Ph}-\mathrm{CH}_{2}\right), 7.21-7.37(\mathrm{~m}, 10 \mathrm{H}, 2 \times P h) .{ }^{1} \mathrm{H}$ NMR $\left(100 \mathrm{MHz}, \mathrm{CDCl}_{3}\right) \delta 7.1,51.0,51.7,56.3,58.1,62.0,69.8,71.6,127.1,127.3,128.3(2 \mathrm{C}), 128.3(2 \mathrm{C}), 128.6$ (2C), $128.6(2 \mathrm{C}), 138.9,139.8$.

(2RS,3SR,4RS,5SR)-1-Benzyl-2-methyl-4-benzylaminopiperidine-3,5-diol (10c) (0.06 g (55\%) was performed from 1-benzyl-6-methyl-4,5-epoxypiperidin-3-ol (9c) $(0.07 \mathrm{~g}, 0.32 \mathrm{mmol})$ and of $\mathrm{BnNH}_{2}(0.04 \mathrm{~g}, 0.32 \mathrm{mmol})$. The crude product was applied to a column packed with silica gel with hexane, gradient elution with system hexane/EtOAC, the content of EtOAc from 30 to 100\%. Reaction time $96 \mathrm{~h}$,, pale yellow crystals, mp 146-147 oc (from EtOAc). Anal. Calcd for $\mathrm{C}_{20} \mathrm{H}_{26} \mathrm{~N}_{2} \mathrm{O}_{2}$ : C, 73.59; $\mathrm{H}, 8.03 ; \mathrm{N}, 8.58$. Found: $\mathrm{C}, 73.44 ; \mathrm{H}, 7.85 ; \mathrm{N}, 8.37 . R_{\mathrm{f}} 0.4$ (hexane /( $\left.\left.\mathrm{CH}_{3}\right)_{2} \mathrm{CO} 2: 1\right) .{ }^{1} \mathrm{H} \mathrm{NMR}\left(400 \mathrm{MHz}, \mathrm{CDCl}_{3}\right) \delta 1.36\left(\mathrm{~d}, J 6.1 \mathrm{~Hz}, 3 \mathrm{H}, \mathrm{CH}_{3}\right), 1.92$ (dd, J 10.9, 10.1 Hz, 1H, $\mathrm{H} 6_{\mathrm{a}}$ ), $2.21\left(\mathrm{dq}, J\right.$ 8.1, $\left.6.1 \mathrm{~Hz}, 1 \mathrm{H}, \mathrm{H} 2_{\mathrm{a}}\right), 2.40$ (dd, J 9.9, $\left.9.6 \mathrm{~Hz}, 1 \mathrm{H}, \mathrm{H} 4 \mathrm{a}\right), 2.87(\mathrm{br} \mathrm{s}, 3 \mathrm{H}, \mathrm{OH}, \mathrm{NH}), 2.95$ (dd, J 10.9, $4.4 \mathrm{~Hz}, 1 \mathrm{H}, \mathrm{H} 6_{\mathrm{e}}$ ), 3.16-3.24 (m, 2H, H3a, Ph-CH), 3.63 (ddd, J 10.1, 9.6, $4.4 \mathrm{~Hz}, 1 \mathrm{H}, \mathrm{H} 5_{\mathrm{a}}$ ), 3.99 (AB-system, J 13.2 $\left.\mathrm{Hz}, 2 \mathrm{H}, \mathrm{Ph}-\mathrm{CH}_{2}\right), 4.07$ (d, J $\left.13.6 \mathrm{~Hz}, 1 \mathrm{H}, \mathrm{Ph}-\mathrm{CH}\right), 7.22-7.38(\mathrm{~m}, 10 \mathrm{H}, 2 \times \mathrm{Ph}) .{ }^{1} \mathrm{H} \mathrm{NMR}\left(100 \mathrm{MHz}, \mathrm{CDCl}_{3}\right) \delta 16.5$, 50.7, 56.8, 57.8, 62.0, 67.9, 68.2, 73.4, 127.1, 127.6, 128.3 (2C), 128.6 (4C), 128.9 (2C), 138.5, 138.6.

$(3 R, 4 r, 5 S)$-1-Benzyl-4-phenylthiopiperidine-3,5-diol (10d) ( $0.18 \mathrm{~g}, 71 \%$ ) was performed from of 1-benzyl-4,5epoxypiperidin-3-ol (9a) (0.15 g, $0.8 \mathrm{mmol})$ and PhSH (0.10 g, $0.8 \mathrm{mmol})$. Reaction time $72 \mathrm{~h}$, pale yellow crystals, mp 229-230 ㅇ (from EtOAc). Anal. Calcd for $\mathrm{C}_{18} \mathrm{H}_{21} \mathrm{NO}_{2} \mathrm{~S}: \mathrm{C}, 68.54 ; \mathrm{H}, 6.71 ; \mathrm{N}, 4.44$. Found: $\mathrm{C}, 68.30$; $\mathrm{H}, 6.52 ; \mathrm{N}, 4.36 . R_{\mathrm{f}} 0.6$ (hexane /( $\left.\mathrm{CH}_{3}\right) \mathrm{CO} 2: 1$ ). ${ }^{1} \mathrm{H} \mathrm{NMR}\left(400 \mathrm{MHz}, \mathrm{DMSO} \mathrm{d}_{6}\right) \delta 2.15\left(\mathrm{brt}, 2 \mathrm{H}, \mathrm{H} 2_{\mathrm{a}}, \mathrm{H} 6_{\mathrm{a}}\right), 2.69(\mathrm{t}, J$ $9.6 \mathrm{~Hz}, 1 \mathrm{H}, \mathrm{H} 4_{\mathrm{a}}$ ), 3.04 (br dd, 2H, H2, $\mathrm{H} 6_{\mathrm{e}}$ ), 3.49 (m, 2H, H3 $3_{\mathrm{a}} \mathrm{H} 5_{\mathrm{a}}$ ), 3.67 (br s, 2H, Ph-CH $), 5.09$ (br s, 2H, OH), 7.21-7.68 (m, 10H, 2xPh). ${ }^{13} \mathrm{C}$ NMR (100 MHz, DMSO d $) \delta 55.1,59.2(2 \mathrm{C}), 59.8,65.1(2 \mathrm{C}), 127.1,129.1(2 \mathrm{C})$, $130.0(2 \mathrm{C}), 132.0(2 \mathrm{C}), 132.4(2 \mathrm{C}), 133.4,135.5$.

$(3 R, 4 r, 5 S)-1-B e n z y l-4-d i a l l y l a m i n o p i p e r i d i n e-3,5-d i o l \quad(10 \mathrm{e})$ and $\quad(3 R S, 4 S R, 5 R S)-1-b e n z y l-5$-diallylaminopiperidine-3,4-diol (10f) were performed similarly to compound 10a from $0.15 \mathrm{~g}$ (0.8 mmol) of 1-benzyl-4,5epoxypiperidin-3-ol (9a) and $0.10 \mathrm{~g}(1.0 \mathrm{mmol})$ of (allyl) ${ }_{2} \mathrm{NH}$. Reaction time $120 \mathrm{~h}$. The crude mixture of isomers $10 \mathrm{e}$ and $10 \mathrm{f}$ was separated chromatographically using a column packed with silica gel in hexane. Elution was performed with a mixture hexane-ethyl acetate, the content of ethyl acetate from 30 to $100 \%$. The major isomer $10 \mathrm{e}(0.16 \mathrm{~g}, 64 \%)$, pale yellow oily substance, $R_{\mathrm{f}} 0.4$ (hexane/ $\left.\left(\mathrm{CH}_{3}\right)_{2} \mathrm{CO} 2: 1\right)$. HRMS for $\left(\mathrm{C}_{18} \mathrm{H}_{27} \mathrm{O}_{2} \mathrm{~N}_{2}[\mathrm{M}+\mathrm{H}]^{+}\right)$Calcd: 303.2067. Found: 303.20719. ${ }^{1} \mathrm{H} \mathrm{NMR}\left(400 \mathrm{MHz},\left(\mathrm{CD}_{3}\right)_{2} \mathrm{CO}\right) \delta 1.89(\mathrm{t}, J 10.2 \mathrm{~Hz}$, $2 \mathrm{H}, \mathrm{H} 2_{\mathrm{a}}, \mathrm{H} 6_{\mathrm{a}}$ ), 2.44 (brt, J $9.4 \mathrm{~Hz}, 1 \mathrm{H}, \mathrm{H} 4 \mathrm{a}$ ), 2.99 (dd, J 10.4, 3,5 Hz, 2H, H2 e H6 $), 3.48\left(\mathrm{~m}, 4 \mathrm{H}, \mathrm{CH}_{2}=\mathrm{CH}_{-} \mathrm{CH}_{2}\right)$, $3.54\left(\mathrm{~s}, 2 \mathrm{H}, \mathrm{Ph}-\mathrm{CH}_{2}\right), 3.7\left(\mathrm{~m}, 2 \mathrm{H}, \mathrm{H} 3_{\mathrm{a}}, \mathrm{H} 5_{\mathrm{a}}\right), 5.14\left(\mathrm{~m}, 4 \mathrm{H}, \mathrm{CH}_{2}=\mathrm{CH}-\mathrm{CH}_{2}\right), 5.90\left(\mathrm{~m}, 2 \mathrm{H}, \mathrm{CH}_{2}=\mathrm{CH}_{-} \mathrm{CH}_{2}\right), 7.21-7.33(\mathrm{~m}$, 
$5 \mathrm{H}, \mathrm{Ph}) .{ }^{13} \mathrm{C} \mathrm{NMR}\left(100 \mathrm{MHz},\left(\mathrm{CD}_{3}\right)_{2} \mathrm{CO}\right) \delta 55.5(2 \mathrm{C}), 60.8(2 \mathrm{C}), 62.9,67.5(2 \mathrm{C}), 71.4,117.9(2 \mathrm{C}), 128.4,129.5$ (2C), $130.2(2 \mathrm{C}), 137.5(2 \mathrm{C}), 138.79$.

The minor isomer $10 \mathrm{f}(0.03 \mathrm{~g}, 12 \%)$, pale yellow oily substance, $R_{\mathrm{f}} 0.5$ (hexane $\left./\left(\mathrm{CH}_{3}\right)_{2} \mathrm{CO} 2: 1\right)$. ${ }^{1} \mathrm{H} \mathrm{NMR}(400$ $\mathrm{MHz}, \mathrm{CDCl}_{3}$ ) $\delta 1.90$ (t, J $10.9 \mathrm{~Hz}, 1 \mathrm{H}, \mathrm{H} \mathrm{a}_{\mathrm{a}}$ ), 2.15 (dd, J 12.4, $1.5 \mathrm{~Hz}, 1 \mathrm{H}, \mathrm{H} \mathrm{a}_{\mathrm{a}}$ ), 2.58 (bs, 2H, OH), 2.93 (ddd, J 11.0, 3.7, $2.2 \mathrm{~Hz}, 1 \mathrm{H}, \mathrm{H} 6_{\mathrm{e}}$ ), 2.98 (dd, J 14.2, $5.1 \mathrm{~Hz}, 2 \mathrm{H}, \mathrm{CH}_{2}=\mathrm{CH}-\mathrm{CH}_{2}$ ), 3.02 (m, 1H, H2 e, 3.12 (ddd, J 10.9, 10.6, 3.8 $\mathrm{Hz}, 1 \mathrm{H}, \mathrm{H} 5 \mathrm{a}$ ), 3.32 (dd, J 14.2, $5.1 \mathrm{~Hz}, 2 \mathrm{H}, \mathrm{CH}_{2}=\mathrm{CH}-\mathrm{CH}_{2}$ ), 3.58 (AB-system, J $\left.13.4 \mathrm{~Hz}, 2 \mathrm{H}, \mathrm{Ph}-\mathrm{CH}_{2}\right), 4.04(\mathrm{~m}, 1 \mathrm{H}$, $\mathrm{H} 3 \mathrm{e})$, 5.08-5.18 (m, 4H, $\left.\mathrm{CH}_{2}=\mathrm{CH}-\mathrm{CH}_{2}\right), 5.75\left(\mathrm{~m}, 2 \mathrm{H}, \mathrm{CH}_{2}=\mathrm{CH}-\mathrm{CH}_{2}\right), 7.23-7.35(\mathrm{~m}, 5 \mathrm{H}, \mathrm{Ph}) .{ }^{13} \mathrm{C} \mathrm{NMR}(100 \mathrm{MHz}$, $\left.\mathrm{CDCl}_{3}\right) \delta 50.4,52,9(2 \mathrm{C}), 56.7,57.6,62.2,67.5,70.2,117.5(2 \mathrm{C}), 127.2,128.3(2 \mathrm{C}), 128.9(2 \mathrm{C}), 136.3(2 \mathrm{C}), 137.4$. Anal. Calcd for $\mathrm{C}_{18} \mathrm{H}_{28} \mathrm{~N}_{2} \mathrm{O}_{2} \mathrm{Cl}_{2}$ (mixture of dihydrochlorides $10 \mathrm{e}$ and $10 \mathrm{f}$ ): $\mathrm{C}, 57.60 ; \mathrm{H}, 7.51 ; \mathrm{N}, 7.47$. Found: C, 57.43; H, 7.39; N, 7.3.

(3R,4r,5S)-4-Aminopiperidine-3,5-diol (11) (0.035 g, 82\%). To 10a (0.10g, 0,32 mmol) in $\mathrm{CH}_{3} \mathrm{OH}(5 \mathrm{ml})$ under in present of $\mathrm{Pd} / \mathrm{C} 10 \%(0,02 \mathrm{~g})$ was hydrogenated at room temperature under atmospheric pressure with monitoring by TLC. The stirring was continued $24 \mathrm{~h}$. Catalyst was filtered off and the solvent was removed on a rotary evaporator. White crystals, $\mathrm{mp} 121-122{ }^{\circ} \mathrm{C}$ (from $\mathrm{CH}_{3} \mathrm{OH}$ /diethyl ether), HRMS for $\left(\mathrm{C}_{5} \mathrm{H}_{13} \mathrm{~N}_{2} \mathrm{O}_{2}[\mathrm{M}+\mathrm{H}]^{+}\right.$) Calcd: 133.0972. Found: 33.09741. ${ }^{1} \mathrm{H}$ NMR (400 MHz, CD $\left.{ }_{3} \mathrm{OD}\right) \delta 2.33$ (dd, J 12.6, 10,6 Hz, 2H, H2 ${ }_{\mathrm{a}}, \mathrm{H} 6_{\mathrm{a}}$ ), $2.48(\mathrm{t}$, J $9.4 \mathrm{~Hz}, 1 \mathrm{H}, \mathrm{H} 4_{\mathrm{a}}$ ), 2.99 (dd, J 12.6, 4,6 Hz, 2H, H2, $\left.\mathrm{H} 6_{\mathrm{e}}\right), 3.28\left(\mathrm{~m}, 2 \mathrm{H}, \mathrm{H} 3_{\mathrm{a}}, \mathrm{H} 5_{\mathrm{a}}, \mathrm{CD}{ }_{3} \mathrm{OD}\right), 4.83(\mathrm{~m}, 5 \mathrm{H}, \mathrm{OH}, \mathrm{NH}$, $\mathrm{NH}_{2}, \mathrm{CD}_{3} \mathrm{OD}$ ). ${ }^{13} \mathrm{C} \mathrm{NMR}\left(100 \mathrm{MHz}, \mathrm{CD}_{3} \mathrm{OD}\right) \delta 52.1(2 \mathrm{C}), 63.0,72.6(2 \mathrm{C})$.

\section{Acknowledgements}

This study was performed with financial support by the Russian Foundation for Basic Research (Grants 14-0300183-a, 11-03-01034-a).

\section{References}

1. Compain, P.; Martin, O.R.; Iminosugars. From synthesis to therapeutic applications. Wiley: Chichester, England, 2007; pp 7-30, 131-149.

2. Stütz, A. E.; Iminosugars as Glycosidase Inhibitors: Nojirimicin and Beyond. Wiley: Weinheim, Germany, 1999, p 10-85.

3. Asano, N.; Nash, R. J.; Molyneux, R. J.; Fleet, G. W. J. Tetrahedron: Asymmetry 2000, 11-36.

4. Asano, N. Curr.Top.Med.Chem. 2003, 3, 471-484. https://doi.org/10.2174/1568026033452438

5. John V.; Moon J.B.; Pulley S.R.; Rich D.H.; Brown D.L.; Jagodzinska B.; Jacobs J.S.; WO Patent 2003043987, 2002-US37037.

6. Hoffmann T.; Koblet A.; Peters J.-U.; Schider P.; Sleight A.; Stadler, H.; U.S.Patent 2005/0090533, 2005.

7. Lohse, A.; Jensen, H.; Bach, P.; Bols, M. J. Chem. Soc., Perkin Trans. 1 2000, 659-665. https://doi.org/10.1039/a908340e

8. Bernotas, R.C.; Ganem, B. Carbohydr. Res. 1987, 167, 312-316. https://doi.org/10.1016/0008-6215(87)80290-2

9. Parr, B.; Horestein, B.A. J. Org. Chem. 1997, 62, 7489-7494. https://doi.org/10.1021/jo9708497

10. Huryn, S.K.; Okabe, M. Chem. Rev. 1992, 92, 1745-1768. 
https://doi.org/10.1021/cr00016a004

11. Rejman, D.; Pohl, R.; Dracinsky, M. Eur. J. Org. Chem. 2011, 11, 2172-2187.

https://doi.org/10.1002/ejoc.201001610

12. José Luis Díaz, J.L.; Fernández-Forner, D.; Bach, J.; Lavilla, R. Chem. Commun. 2008, 2799-2813.

13. Alcaide, B.; Almendros, P.; Cabrero, G.; Ruiz, M.P. J. Org. Chem. 2007, 72 (21),7980-7991. https://doi.org/10.1021/jo701452a

14. Olofsson, B.; Bogar, K.; Fransson, A-B.L.; Backvall, J-E. J.Org.Chem. 2006, 71, 8256-8260. https://doi.org/10.1021/jo0615091

15. Amat, M.; Escolano, C.; Lozano, O.; Llor, N.; Bosch. J. Org. Lett. 2003 , 5, 3139-3142. https://doi.org/10.1021/ol035199+

16. Terán, A.O.; Concellón, J.M.; Rivero, I.A. Arkivoc, 2009, (ii) 288-297. http://dx.doi.org/10.3998/ark.5550190.0010.227

17. Veselov, I.S.; Trushkov, I.V.; Zefirov, N.S.; Grishina G.V. Russ. J. Org. Chem. 2009, 45, 1062-1072 . (Zh.Org. Khim., 2009, 45, 1062-1072).

18. Grishina, G. V.; Veselov, I. S.; Nelyubina, Y. V.; Surovaya, A. N.; Zefirov, N. S. Arkivoc, 2011, (x), $107-117$. http://dx.doi.org/10.3998/ark.5550190.0012.a09

19. Tokuda, O.; Aikawa, T.; Ikemoto, T.; Kurimoto, I. Tetrahedron Lett. 2010, 51, 2832-2834. https://doi.org/10.1016/j.tetlet.2010.03.061

20. Scheunemann, M.; Hennig, L.; Funke, U.; Steinbach, J. Tetrahedron 2011, 67, 3448-3456. https://doi.org/10.1016/j.tet.2011.03.045

21. Villar-Barro, A.; Gotor,V.; Brieva, R. Tetrahedron 2015, 71, 6907-6912. https://doi.org/10.1016/i.tet.2015.07.014

22. Ortiz, A.; Young, I. S.; Sawyer, J. R.; Hsiao, Y.; Singh, A.; Sugiyama, M.; Corbett, R. M.; Chau, M.; Shi, Z.; Conlon, D. A. Org. Biomol. Chem. 2012, 10, 5253-5257.

https://doi.org/10.1039/c2ob25411e

23. Young, I. S.; Ortiz, A.; Sawyer, J. R.; Conlon, D. A.; Buono, F. G.; Leung, S. W.; Burt, J. L.; Sortore, E. W. Process. Dev Res Org. 2012, 16, 1558-1565.

https://doi.org/10.1021/op300174w

24. Grishina, G.V.; Veselov, I.S.; Safronova, E. N.; Mazur, D.M.; Samoshin, V.V. Tetrahedron Lett. 2017, 58, (21), 2019-2022. https://doi.org/10.1016/i.tetlet.2017.04.017

25. Mazur, D.M.; Grishina, G.V. Lebedev, A.T. J. Pharm. Biomed. Anal. 2017, 140, 322-326. https://doi.org/10.1016/i.jpba.2017.03.066

26. Grishina, G.V.; Borisenko, A.A.; Veselov, I.S.; Petrenko, A.M. Russ. J. Org. Chem. 2005, 41, 272-278. (Zh. Org. Khim., 2005, 41, 281-287). https://doi.org/10.1007/s11178-005-0156-4

27. Miyashita, K.; Park, M.; Adachi, S.I.; Seki S.; Obika, S.; Imanishi, T. Bioorg. Med. Chem. Lett. 2002, 12, (7), 993-1144.

https://doi.org/10.1016/S0960-894X(02)00085-9

28. Kawada, Y.; Kodama, T.; Miyashita, K.; Imanishi, T.; Obika, S. Heterocycles 2010, 80, 1249-1265. https://doi.org/10.3987/COM-09-S(S)112

29. Ouchi, H.; Mihara, Y.; Watanabe, H.; Takahata, H. Tetrahedron Lett. 2004, 45, 7053- 7056. https://doi.org/10.1016/i.tetlet.2004.07.127

30. Eliel, E.L.; Wilen, S.R.; Doyle, M.P. Basic Organic Stereochemistry, Wiley: New York, parts 9-11. 